\title{
口腔悪性腫瘍切除創に対する植皮例の検討
}

\author{
石川義人・工藤啓吾・久慈昭慶・横田光 正 \\ 山口一成・大屋高徳・藤岡幸雄
}

\section{Skin graft for wounds after surgery of the oral malignant tumors}

\author{
Yoshihito Ishikawa - Keigo Kudo - Akiyoshi Kujr - Mitsumasa Yokota \\ Kazushige Yamaguchi - Takanori OYA - Yukio FujIOKA
}

\begin{abstract}
Seven split and 3 full thickness skin grafts for malignant tumors after radiotherapy were performed for the following purposes: Biological dressing and promotion of healing for resection wounds and retention of the reduction after marsupialization wounds of the maxillary sinus. The skin grafts were used for reconstruction of defects following surgery of the smaller superficial tumors. All grafts were taken from femoral skin. Recipient sites were as follows; 1 maxilla, 5 maxillae and buccal mucosae, 3 mandibles and 1 tongue. In 10 patients preoperative chemotherapy was carried out and also in 8 of them irradiation of 10-88 Gy.

All grafts were alive and a necrotic bone piece each was found in the wounds of a maxilla and a mandible 1 or 2 months later. The skin grafts were very useful for insertion of denture except 1 patient with teeth and satisfactory results were obtained.
\end{abstract}

Key words: skin graft, surgical wound, malignant tumor

緒

$\overline{\overline{\bar{一}}}$

口腔領域の悪性腫瘍に対する放射線治療後の切除創 は，創傷治瘉の遅延や骨壊死，あるいは廄痕拘縮などを 後遣することがある。このよらな症例に対し，椺が広 範用で，かつ深在性の畽瘍に対しては有茎皮弁 ${ }^{(\sim 3)}$ を用 いて再建しているが，逆に欠損が比較的小範囲で表在性 の腫瘍にはむしろ生着の良好な植皮が有用と考えてい る.

そこで，われわれは主として照射後の顎骨切除創の骨 壊死の予防や切除創面の生物学的保護ならびに治痰促 進，あるいは上顎洞癌治療後における開洞部の縮小防止 などの目的で，主に分層植皮を試みた。その結果，顎義 歯の装用にかなりの有用性がみられ，ほぼ満足できる成 績が得られたので報告する

岩手医科大学菌学部口腔外科学第 1 講坐

（主任：藤岡幸雄教授）

First Department of Oral and Maxillofacial Surgery, School of Dentistry, Iwate Medical University (Chief: Prof. Yukio Fujioka)

受付日：昭和 62 年 3 月 9 日

\section{対 象 症 例}

症例は1980年12月から1986年 1 月までの約 5 年間に, 悪性腫瘳切除後に植皮を行った10例である。これらの年 踰，性別，原疾患は表1のごとくであった。これら10症 例は，一次症例が 5 例，二次症例が 5 例であった。 ま た，植皮前治療として，すべての症例に対し化学療法 が，また10例中 8 例には術前照射が10〜88 Gy，平均 38 Gy がなされていた。また，顎骨切除は上䫟部分切除が 6 例，下顎部分切除が 3 例および舌部分切除が 1 例に施 行された（表1）。

術 式

恵皮部はすべて大腿部で，あらかじめ口腔内の欠損範 囲を濾紙で計測し，ピオクタニンを用いて大腿部に作図 した．植皮片の採取は初期の 2 例は free hand dermatome で, その後の 8 例は air dermatome (ハウメディ カ社製 DR-0255-500 S) で採取した（写真 $1 \mathbf{A}, \mathbf{B}$ ). 植皮片の大きさは $3 \times 6 \mathrm{~cm}$ から $13.5 \times 7.5 \mathrm{~cm}$ で，ま た厚さは $0.2 \mathrm{~mm}$ (薄目の分層植皮) から $1.0 \mathrm{~mm}$ (全 
表 1 症例の概要

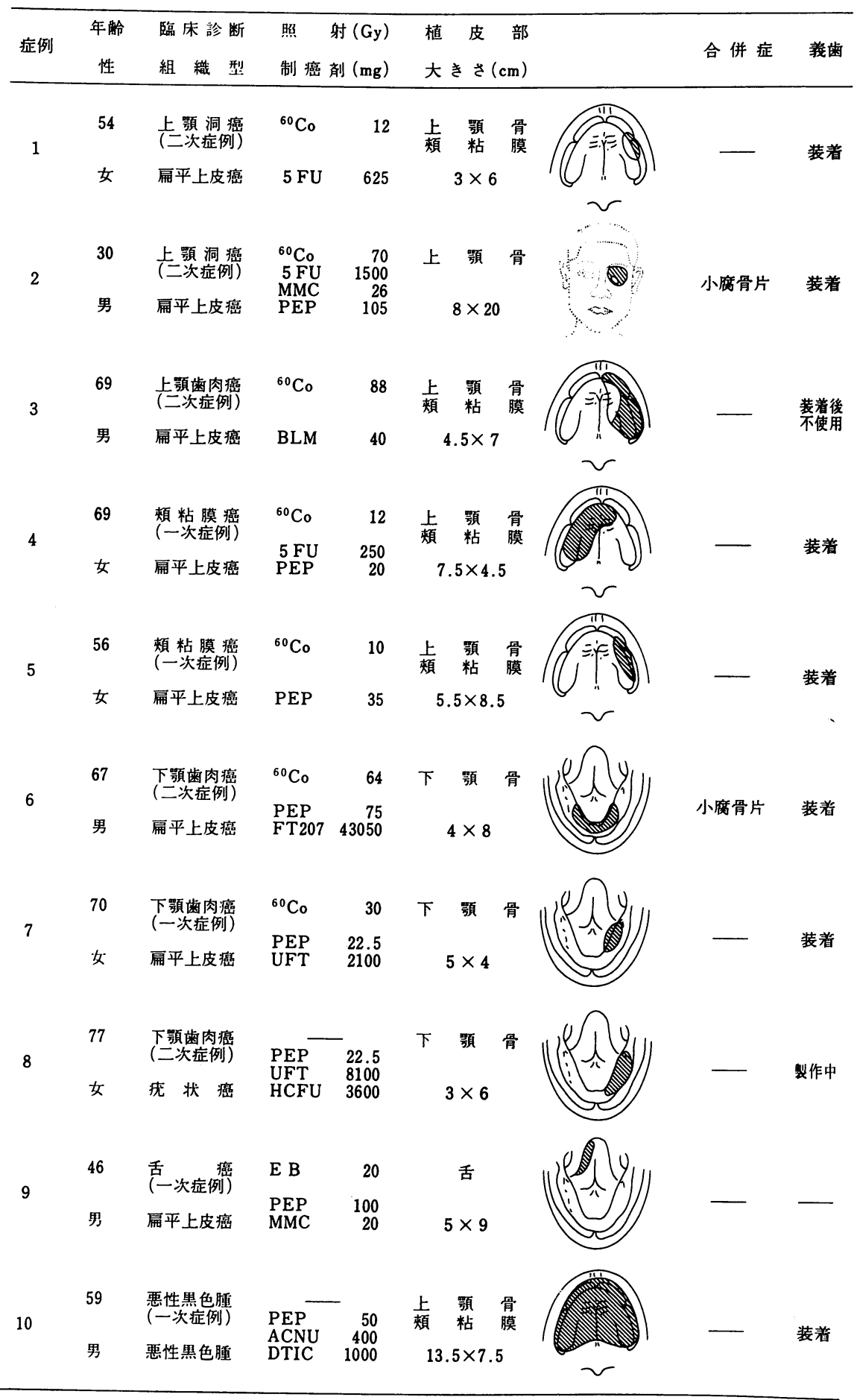




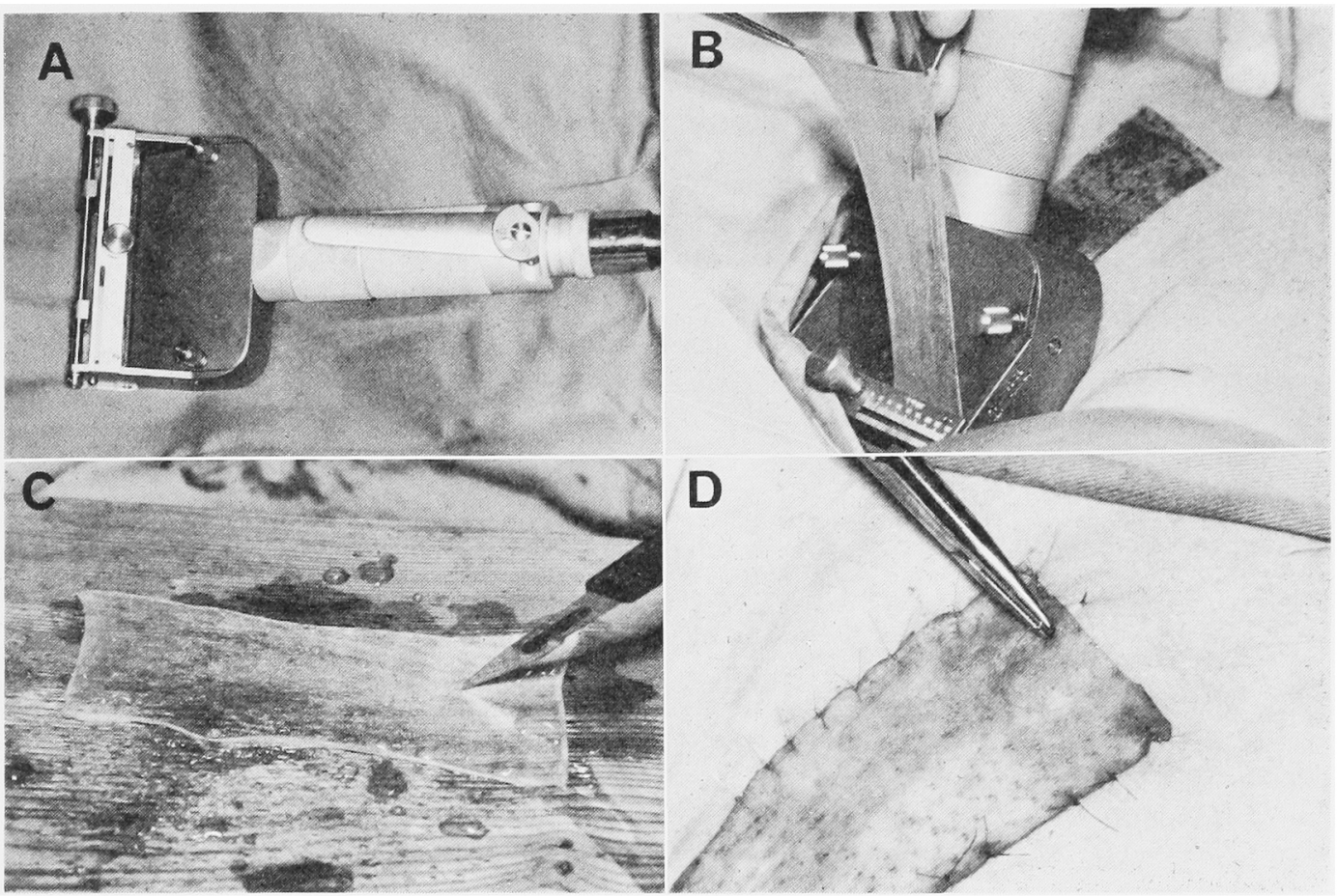

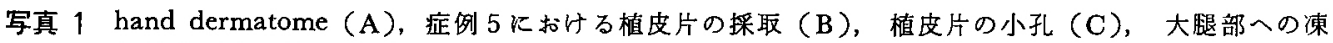
結乾燥豚皮の縫合 (D)

增植皮)であった，採取片は止血を敩重に行ってから細 菌感染の防止をはかり，絹禾にて周囲組織に密に縫合し た。な拉，血液の貯溜を予防するために植皮片に小孔を あけた（写真1 C)．恵皮部は止血確認後，凍結乾燥豚 皮である LPS (Alloask: 大鵬) をナイロン糸にて 﨔合 し（写真１D），その上にシリコンガーゼをあてた。 さらに，その上に抗生物質含有軟育を塗布し，綿花を置 き tie-over 固定を施し，7〜10 日間にわたって 固定し た.

植皮部は煩粘膜に及ぶ上顎骨 5 例，舌 1 例，上顎骨の み 1 例，下頻骨 3 例であった．固定はテトラサイクリン 軟高付ガーゼの tie-over 固定を行った。 その期間は7 〜10日で，その間は释管栄荃とした。

\section{結果}

われわれが腫瘍切除後に植皮を行った10例では，植皮 片はすべて生着した，とくに，高線量照射例においても 著明な骨障害はみられなかった，植皮片の厚さは全層植 皮が 3 例，分層植皮が 7 例で，上頻骨の血行良好例では 全層植皮（写真 2) を行っても，全く異常なく良好な生 着をみた，また，血行の悪い下顎骨や高線量照射 例て は，やや薄目の分層植皮（写㗄了〜 5) を行らことによ り，良好な結果が得られた。植皮後に一部小腐骨片が10
例中 2 例にみられ，これらは容易に除去することができ たそその後，創は周囲組織の肉芽化により閉鎖した。 た，有霜靧である 1 例を除き，顎義處の装着が可能であ った.

考察

放射線治療後の䫇骨切除創は, 術後の義歯装着が困難 となり，咀嚼および発音などの機能に問題を残すことが 多い，今回，われわれは部位により厚さを加滅した植皮 を応用し，相対的に宷槽堤を形成 これら機能の回復を図った。

分詹植皮は薄いほど生着しやすく，また露出骨面に対 しては全層植皮に比べて生着しやすい，しかし，術後の 二次収緶が問題となり，とくに薄いはど収縮が大き (5)。一方，惠皮部は母床とのカラーマッチ，厚さ，皮 周附属器官の有無, 血行などに注意して選択されるべき である6). しかし，口腔内への植皮は，それほどカラ一 マッチを考虑する必要がない，また，審美的にできるだ け衣服にかくれるところが好ましく， dermatome で採 取するためになるべく平らなところが選ばれる，その点 では大腿部，腹部，筒部などが好ましいが，われわれは 術中の操作性の容易さから，すべて大腿部から採取し た. 


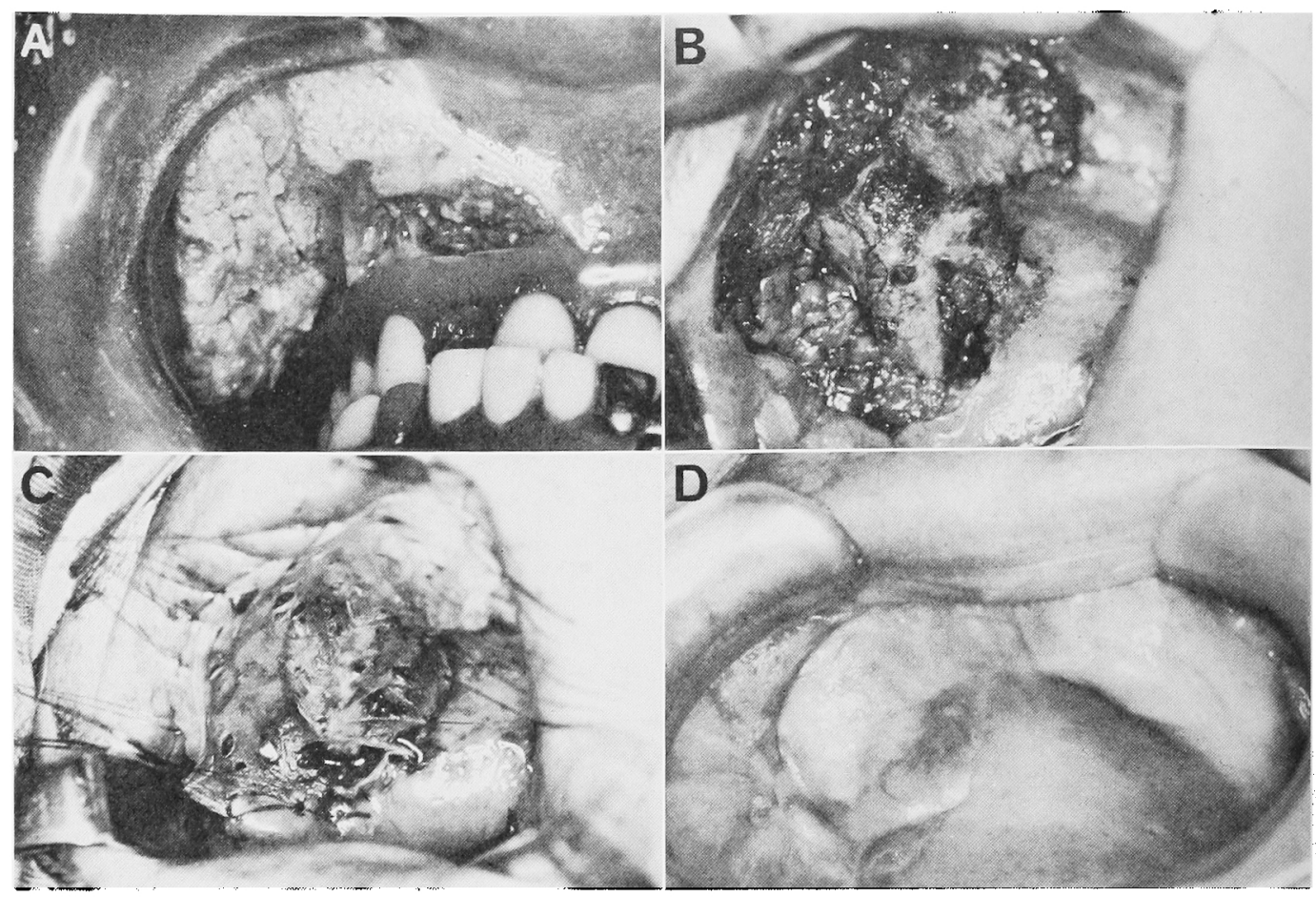

写真 2 症例 5 の初診時 (A), 腫瘍切除時の骨面 (B)，植皮片の䋖合 (C)，5か月後の植皮 (D)
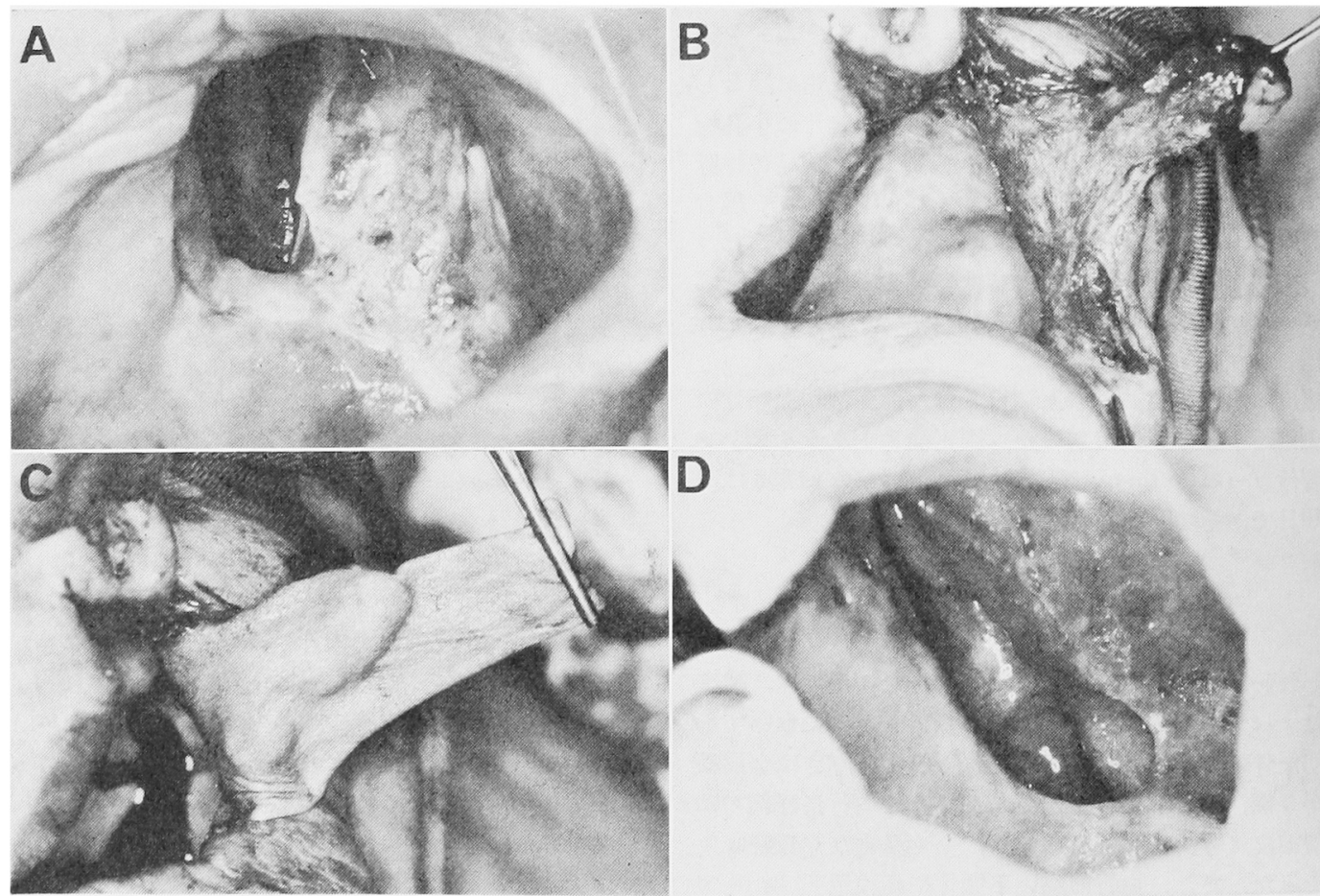

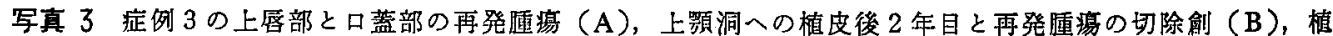
皮片の綎合 (C)，6 月月後の植皮 (D) 

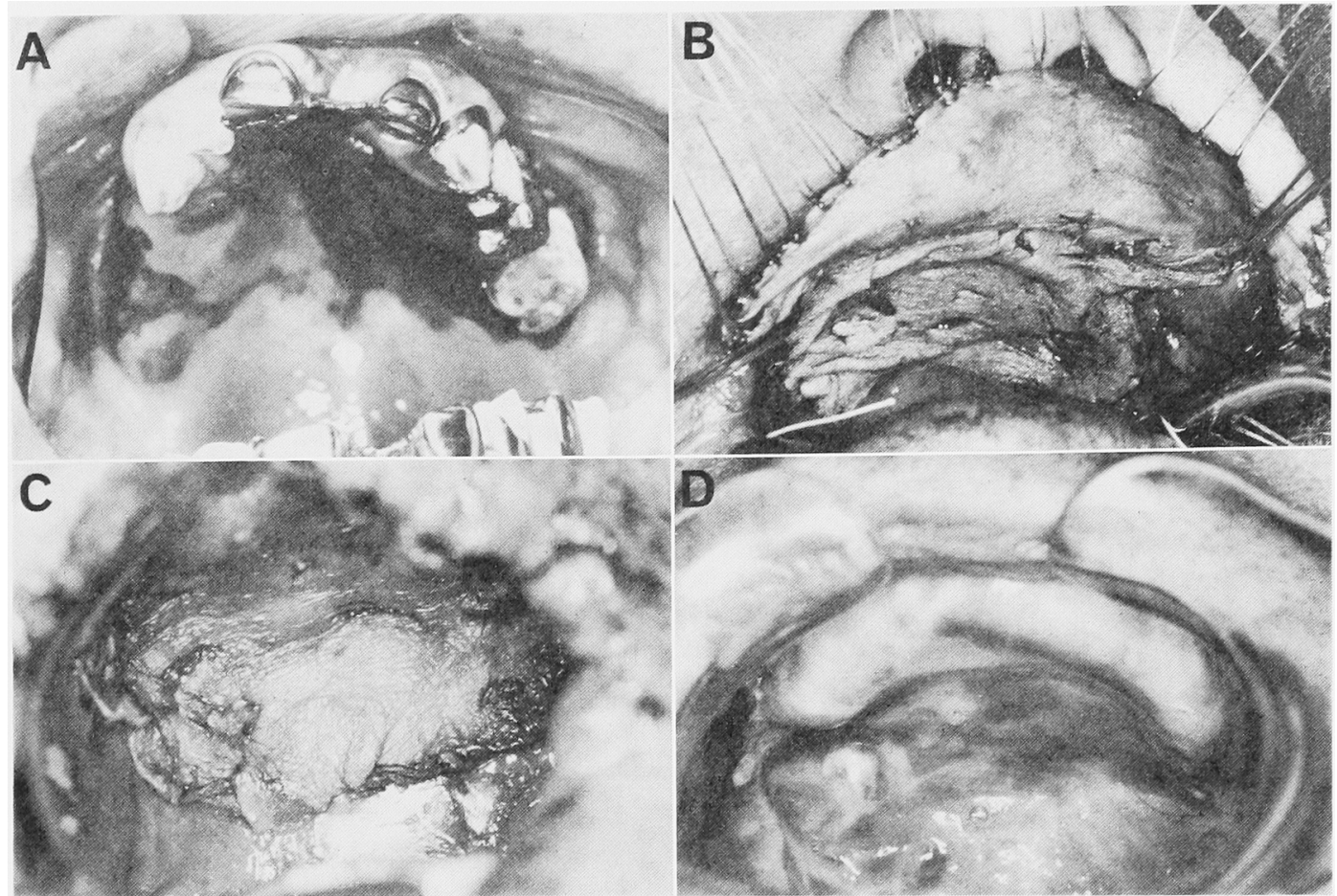

写真 4 症例10の初診時（A），植皮片の繾合（B），8日目の tie-over 固定の除去（C），7 加後の 植皮 (D)
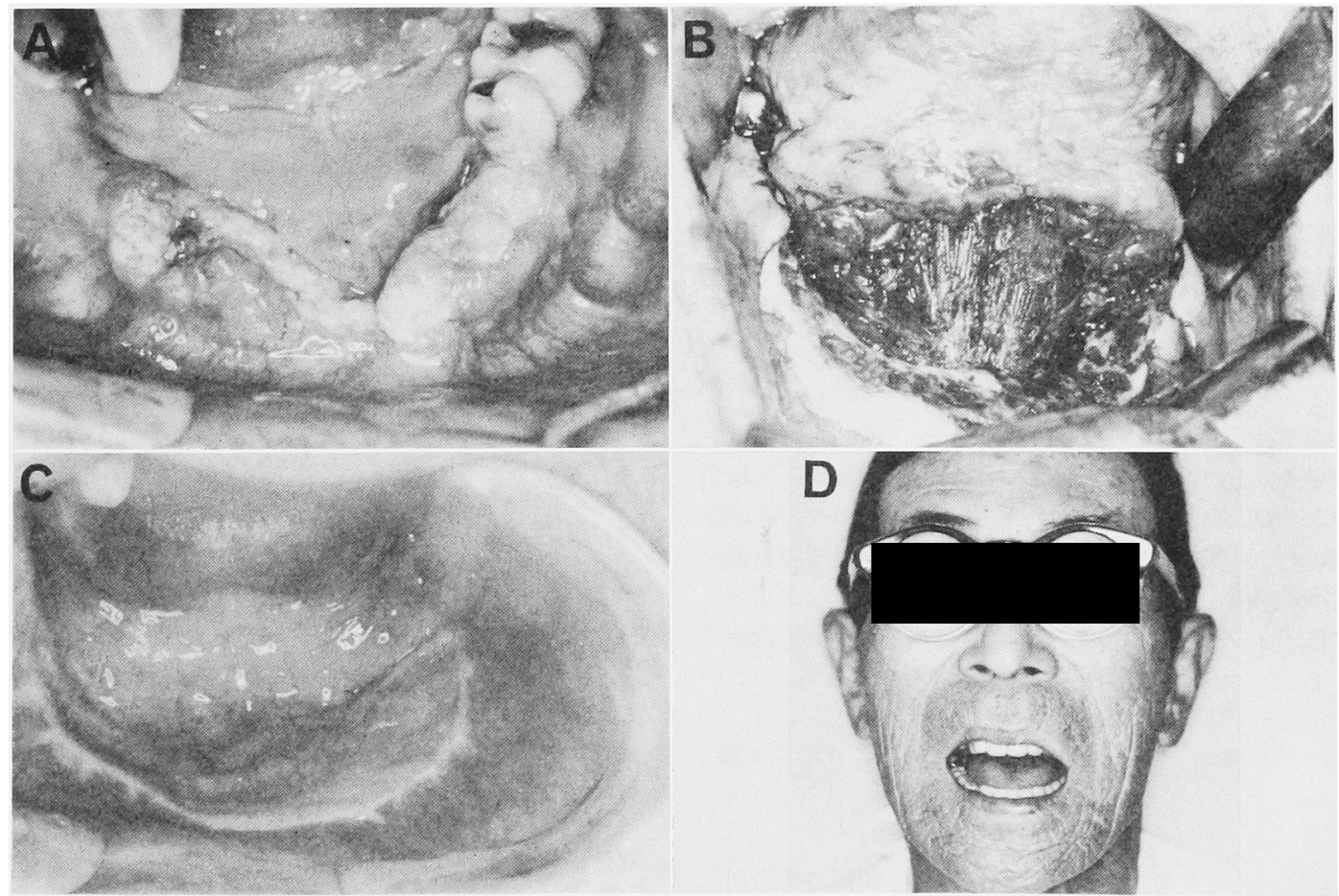

写真 5 症例 6 の初診時腫瘍 (A)，切除時の露出骨面 (B)，1 年 3 か月後の植皮 (C), 同時期の総義菌 装着時の顔貌（D） 
一方, 全層植皮は母床の血行が不良な場合は生着しに くく，そのため露出骨面への生着はあまり期待できない が, われわれの経験した症例は血行の良い上顎骨への植 皮であったためか，とくに問題なく生着した。しかし，

一般的には二次収縮は小さいが，感染には弱いといわれ ている，恵皮部には耳介後部，鎖骨上窝，前胸部，肘窝 部, 鼠径部などがあげられている7が，大腿部から採取し てもとくに䑤痕が問題となることはなかった。 また，口 腔粘膜の移植 ${ }^{8)}$ も報告されている. しかし, 形態的, 機 能的には理想的であるが，実際には採取量が少なく，悪 性腫崵のような大きい欠損には適応し難い。この際は, むしろ遠隔部からの植皮が適応寸ると考えている。植皮 の欠点は生着後に発毛および角化などがみられることで ある。これらを補らべく上田ら ${ }^{9,10)}$ は，反転真皮移植を 行い，良好な成績が得られたと報告しており，今後の発 展が期待される。

口腔癌に対する放射線治療後の骨壊死は全体の $5 \sim 15$ \% ${ }^{10,11)}$ であるとされ，その原因は高線量照射や抜歯およ び義歯の刺激などによる外傷や感染，あるいはまた病変 が骨に近接した腫湟の場合などが指摘されている13)。骨 壊死に至る線量は Woodward ら ${ }^{14)} は ， 50 \mathrm{Gy，またBe-}$ dwinek ら ${ }^{15)}$ は $70 \mathrm{~Gy}$ 以上になると $9 \%$ そられたと 報告している，われわれの10症例における術前照射線量 は10〜88 Gy, 平均 $38 \mathrm{~Gy}$ であった。 しかし, 術後 に小腐骨片のみられたものは上下靧の各 1 例の久であっ た。照射と化学療法の併用例は非併用例に比べて早期に 骨障害が発現 ${ }^{13)}$ しやすいといわれている。しかし，われ われの10症例では広籁な骨壊死はみられなかった。一 方，われわれの顎骨切除に対する方針は，広範囲な腫場 に対しては部分切除や半側切除を行い，欠損部を有茎皮 升を用いて再建している( ${ }^{123}$ しかし，浅在性腫暗の場 合は靧骨を保存した切除を行った後に植皮を行っている が，広範な骨壊死の発症はみられなかった。したがっ て，このよらな場合の植皮は放射線性骨壊死の予防にも 役立っているように思われた。

いらまでもなく，悪性腫場の切除は広範囲に行うこと が再発防止のために不可欠である。したがって，切除創 が比較的広籁囲に及ぶときは，遠隔部からの皮弁や植皮 が適応されるべきである。また，再三にわたる再発癌の 1 例（症例 3 ）では, 植皮後の再発がみられなくなって おり，この点植皮は上皮性悪性腫瑒の再発防止のために もなんらかの関連性があるのではないかと推察してい る.

\section{結}

\section{語}

われわれは放射線治療後の悪性腫㻛症10例の切除創部 に対して植皮を行ったところ，これらはすべて生着し， その後, 小腐骨片の発生したものが上下顎おの拉の 1 例
のみであった。 また，有歯䫓である 1 例を除けば、ほと んどの症例で䪽義歯の装着が可能であった。

本論文の要旨は1986年10月16日の第31回日本口腔外科 学会 (於：久留米市) に打いて口演, 発表した。

\section{引用 文 献}

1）工藤啓吾, 柘植信夫, 他: Cervical island skin flap に上る口腔癌切除後の即時再建. 日口外誌 31: 661-666 1985.

2）工藤啓吾, 柘植信夫, 他：大胸肪皮升に上る口腔 癌切除後の即時再建. 日只外誌 29: 514-521 1983.

3）工藤啓吾, 柘植信夫, 他：各種皮弁に上る口腔・ 顎・顔面欠損の再建之臨床経過汇関寸る検討。日 口外誌 31：2323-2332 1985.

4) 山崎正, 野村健, 他: 口腔恶性腫㻛再建症例 に打㤝全層遊離皮層移植に上る 2 期的菌槽堤形 成術。 日外誌 31: 777-783 1985 .

5) 鬼塚卓弥：形成外科手術書. 第 2 版, 南江堂, 東 京, 1982，67-68面.

6) 鬼塚卓弥, 編：標準形成外科学。第 1 版, 医学書 院, 東京, 1975, 26頁。

7) 合田喜一郎, 編：形成外科学入門。第 1 版, 南山 堂, 東京, 1978, 46頁。

8）高橋庄二郎, 重松知寞, 他：遊離煩粘嗼移植に上 る很後両㑡毙裂患者の罰間骨口腔前庭形成術. 日 口外誌 21: 782-787 1975.

9）上田実, 長山勝, 他：反転真皮移植に上る口 腔粘膜再建の検討一その基礎生物学的背景拉上び 臨床応用一 日外誌 31: 1319-1327 1985.

10）上田実, 江口吾郎：口腔粘膜の再構成一自家真 皮反枟移植から培淠勫胞による人工粘膜の再構成 へ—. 病態生理 5: 538-544 1986.

11）奥山武雄, 堀内淙一。他：口腔領域に扣ける放射 線骨障害（いわゆる放射線骨壊死）に関する考察 一第 1 報 発生頻度とX線写真所見について一。 䧗床放射線 14:472-481 1969.

12) Watson, W.L., and Scarborough, J.E.: Osteoradionecrosis in intraoral cancer. Amer $\mathrm{J}$ Roentgenol 40: 524-534 1938.

13）岡田豊, 逢坂文博, 他: 口腔癌の放射線治㙩见

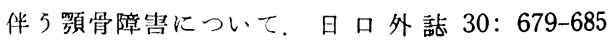
1984.

14) Woodward, H.Q and Coley, B.L.: The correlation of tissue dose and clinical response in irradiation of bone tumor and of normal bone. Amer J Roentgenol 57: 464-471 1947.

15) Bedwinek, J.M., Shukovsky, L. J., et al.: Osteonecrosis in patients treated with definitive radiotherapy for squamous cell carcinomas of the oral cavity and naso-and oropharynx. Radiology 119: 665-668 1976. 